\title{
Fire history in western Patagonia from paired tree-ring fire-scar and charcoal records
}

\author{
A. Holz ${ }^{1, *}$, S. Haberle ${ }^{2}$, T. T. Veblen ${ }^{1}$, R. De Pol-Holz ${ }^{3,4}$, and J. Southon ${ }^{4}$ \\ ${ }^{1}$ Department of Geography, University of Colorado, Boulder, Colorado, USA \\ ${ }^{2}$ Department of Archaeology and Natural History, College of Asia \& the Pacific, Australian National University, \\ Canberra, ACT 0200, Australia \\ ${ }^{3}$ Departamento de Oceanografía, Universidad de Concepción, Chile \\ ${ }^{4}$ Department of Earth System Sciences, University of California, Irvine, California, USA \\ * present address: School of Plant Sciences, University of Tasmania, Hobart 7001, Australia
}

Correspondence to: A. Holz (andres.holz@utas.edu.au)

Received: 2 September 2011 - Published in Clim. Past Discuss.: 10 October 2011

Revised: 25 January 2012 - Accepted: 27 January 2012 - Published: 9 March 2012

\begin{abstract}
Fire history reconstructions are typically based on tree ages and tree-ring fire scars or on charcoal in sedimentary records from lakes or bogs, but rarely on both. In this study of fire history in western Patagonia $\left(47-48^{\circ} \mathrm{S}\right)$ in southern South America (SSA) we compared three sedimentary charcoal records collected in bogs with tree-ring firescar data collected at 13 nearby sample sites. We examined the temporal and spatial correspondence between the two fire proxies and also compared them to published charcoal records from distant sites in SSA, and with published proxy reconstructions of regional climate variability and large-scale climate modes. Two of our three charcoal records record fire activity for the last $4 \mathrm{ka} \mathrm{yr}$ and one for the last $11 \mathrm{kayr}$. For the last ca. $400 \mathrm{yr}$, charcoal accumulation peaks tend to coincide with high fire activity in the tree-ring fire scar records, but the charcoal records failed to detect some of the fire activity recorded by tree rings. Potentially, this discrepancy reflects low-severity fires that burn in herbaceous and other fine fuels without depositing charcoal in the sedimentary record. Periods of high fire activity tended to be synchronous across sample areas, across proxy types, and with proxy records of regional climatic variability as well as major climate drivers. Fire activity throughout the Holocene in western Patagonia has responded to regional climate variation affecting a broad region of southern South America that is teleconnected to both tropical- and high-latitude climate drivers-El NiñoSouthern Oscillation and the Southern Annular Mode. An early Holocene peak in fire activity pre-dates any known human presence in our study area, and consequently implicates lightning as the ignition source. In contrast, the increased fire activity during the 20th century, which was concomitantly
\end{abstract}

recorded by charcoal from all the sampled bogs and at all fire-scar sample sites, is attributed to human-set fires and is outside the range of variability characteristic of these ecosystems over many centuries and probably millennia.

\section{Introduction}

Fire is increasingly recognized as a keystone disturbance process in southern South America (SSA) (Veblen et al., 2003, 2011; Whitlock et al., 2007). However, the relative contribution of deliberate burning by prehistoric peoples versus control primarily by regional climate variation remains uncertain and controversial (Heusser 1994; Markgraf and Anderson, 1994). Different interpretations of the contributions of humans to fire history variability may reflect the coarse spatial and temporal resolution at which most records of fire and land use have been examined. The goal of the current study is to improve our understanding of fire history reconstructions by comparing long-term, sedimentary charcoal with nearby fire scar chronologies in temperate rainforests in western Patagonia (Fig. 1).

In southern South America, fire history reconstructions commonly have been based on two approaches: (a) dendrochronological dating of fire scars and stand ages (Veblen and Lorenz, 1987; Kitzberger and Veblen, 1997) and (b) dating of charcoal from sedimentary records from lakes or bogs (Heusser, 1987; Whitlock and Anderson, 2003). Each of these techniques has unique strengths and weaknesses: treering studies have annual (and sometimes even seasonal) temporal resolution and usually have an easily specified spatial 


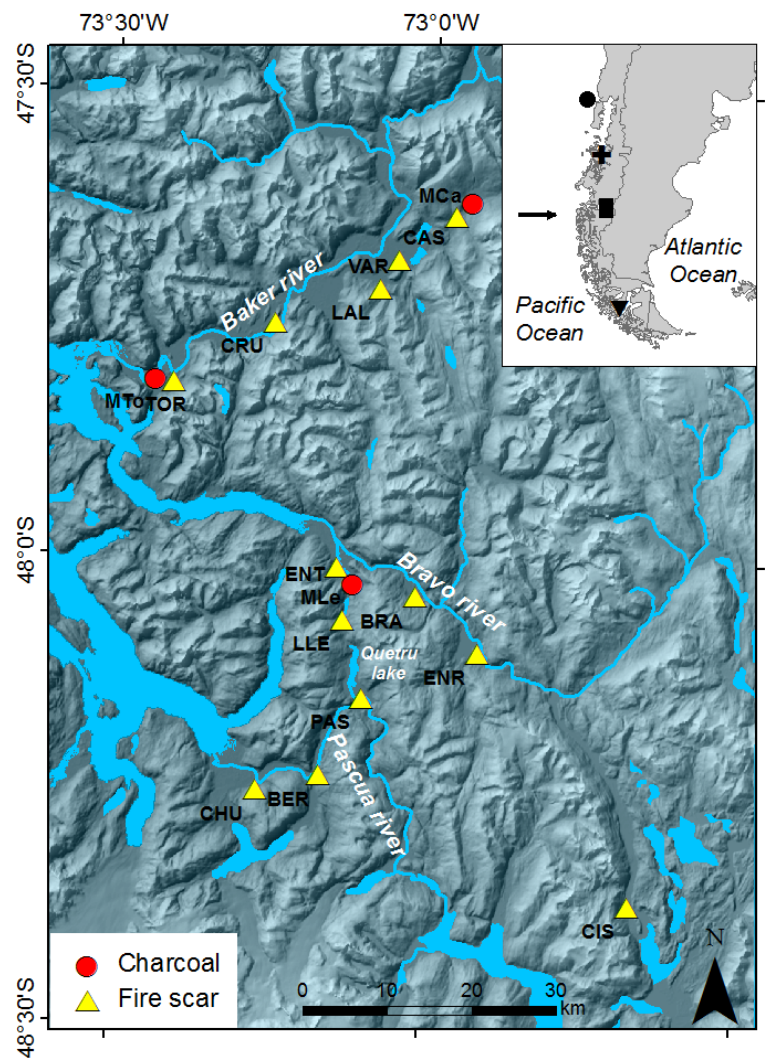

Fig. 1. Map of the study area in central Patagonia showing coring and fire scar sites in the Baker, Bravo and Quetru-Pascua watersheds. In the inset map of southern South America (SSA), black rectangle, arrows, black circle, black cross, and black triangle represent the study area, the southerly westerly winds (SWW) predominant direction and latitudinal fluctuation, precipitation reconstructions (and hence, the position of the SWW) at $41^{\circ} \mathrm{S}$ (Lamy et al., 2001), $44^{\circ} \mathrm{S}$ (Sepúlveda et al., 2009), and $53^{\circ} \mathrm{S}$ (Lamy et al., 2010), respectively. Site characteristics are outlined in Tables S1 and S2 in the Supplement.

resolution. However, fire-scar records are typically only robust over a few centuries and rarely can reliably capture changes in fire activity beyond a millennium. In contrast, charcoal-based fire history reconstructions can extend back for millennia, but in general have comparatively poor temporal resolution (typically supra-decadal resolution) that impedes analyses of fire variability to interannual scale variability in climate drivers such as ENSO. The spatial extent of burning associated with a charcoal sedimentary record also may be difficult to determine (Whitlock and Anderson, 2003). Although the combined use of these two proxy types may provide complementary information and can improve interpretation of past fire activity, such studies are relatively uncommon (Clark, 1990; Whitlock and Anderson, 2003; Allen et al., 2008; Higuera et al., 2010a).

Fire history research in southern South America (SSA) based on short-term documentary fire records, tree-ring reconstruction of fire, and sedimentary charcoal records are all contributing to an improved understanding of how variability in major climate drivers affect regional climate variability and in turn wildfire activity. In northern Patagonia in Argentina (39-42 $\mathrm{S}$, eastward of the Andes), both documentary fire records (post-1937) and multi-century tree-ring fire records of fire reflect strong ENSO influences of fire (Kitzberger and Veblen, 1997, 2003; Veblen et al., 1999; Kitzberger 2002; de Torres Curth et al., 2008). Similarly, in south-central Chile ( $39^{\circ} \mathrm{S}$, westward of the Andes) tree-ring reconstructed fire history over the past several centuries is significantly related to ENSO (González and Veblen, 2006). Likewise, changes in fire regimes derived from charcoal and pollen records in the middle to late Holocene over a broad area of Patagonia have been related to the onset and subsequent intensification of ENSO at $\sim 6$ and/or $\sim 3 \mathrm{ka}$ yr (Whitlock et al., 2006; Abarzúa and Moreno, 2008; Moreno et al., 2010a). Variability in high-latitude circulation patterns related to the latitude and strength of the southern westerly winds (SWW) is also reflected in interannual to millennialscale variability in wildfire activity in SSA (Veblen et al., 1999; Whitlock et al., 2007). For example, analyses of treering fire history records from 42 to $48^{\circ} \mathrm{S}$ (westward of the Andes) related wildfire activity to variability in the Southern Annular Mode (SAM) which is the principal extratropical driver of climate variability in the Southern Hemisphere (Holz and Veblen, 2011a). Furthermore, when tropical sea surface temperatures are in a warm phase, the fire-enhancing influence of positive SAM in western Patagonia is intensified (Holz and Veblen, 2011b). Similarly, analyses of postsatellite era (1979-2003) climate patterns indicate that intensities of regional climate teleconnections to either ENSO or SAM are contingent on phases of both drivers (Pezza et al., 2008).

Holocene patterns of fire derived from spatially coarsescale charcoal records reveal some regionally consistent patterns most likely related to major climate shifts (Whitlock et al., 2007; Moreno et al., 2010b; Fletcher and Moreno, 2011a). These include increased burning in the early Holocene as a result of warming conditions at the end of the glaciations and possible weakening and/or southward shifts in storm tracks. Latitudinal differences in fire patterns in the middle Holocene imply increased summer precipitation at mid-latitudes (Whitlock et al., 2007). However, regionally variable fire activity in the late Holocene may reflect either increased interannual to inter-decadal climate variability related to ENSO or increased burning by Native peoples or both. Improved understanding of the causes of this variability, especially in the late Holocene, require a more complete network of charcoal and tree-ring fire records as well as better resolved records of pre-historic human activities. We base our interpretation of charcoal and fire-scar records from western Patagonia on new reconstructions of archaeological and ethnohistorical records of human activities in western Patagonia (Holz and Veblen, 2011c) as well as proxy records 
spanning most of the Holocene of the position and strength of the SWW (Lamy et al., 2010) and of ENSO (Moy et al., 2002; Koutavas and Sachs, 2008).

Previous charcoal and tree-ring fire histories in SSA are for locations in central, south-central Chile and northern Patagonia at 34-46 $\mathrm{S}$ (Heusser, 1983; Kitzberger and Veblen, 1997; Veblen et al., 1999; Moreno, 2000; González and Veblen, 2006; Whitlock et al., 2006; Markgraf et al., 2007; Abarzúa and Moreno, 2008; Holz and Veblen, 2011c) or in the far south of Patagonia and Tierra del Fuego at 5155 $5^{\circ}$ (Huber and Markgraf, 2003; Huber et al., 2004; Markgraf and Huber, 2010). For western Patagonia to the windward side of Andes south of $42^{\circ} \mathrm{S}$ there is only one published micro-charcoal record (non-contiguous sampling) at $44^{\circ} \mathrm{S}$ (Haberle and Bennett, 2004), and there are no charcoal records in western Patagonia from 46 to $51^{\circ} \mathrm{S}$. In the present study, we use paired records of charcoal and tree-ring fire histories to examine variability in wildfire activity at 47 to $48^{\circ} \mathrm{S}$ in western Patagonian rainforests. Our primary objectives are to compare fire records derived from sedimentary charcoal with nearby tree-ring fire records, and to evaluate the reliability of inferring fire activity from bog charcoal records alone for the ca. 1500-2000 AD period. To attain these objectives, we: (a) developed long term charcoal records from 3 newly sampled bogs, and (b) compared the temporal and spatial correspondence between these charcoal records with nearby tree-ring reconstructed fire histories (Holz and Veblen, 2011c). Finally, we compare our charcoal records for western Patagonia with published proxy reconstructions of regional climate and of broad-scale climate drivers as well as records of local pre-historic and historic human presence and land use (Holz and Veblen, 2011c).

\section{Material and method}

\subsection{Sampling sites}

\subsubsection{Study area}

Records of wildfire activity were produced by sampling sedimentary charcoal at three ombrotrophic peat bogs and firescarred trees at 13 sample sites located in the Baker, Bravo, and Quetru-Pascua rivers watersheds (Fig. 1; Tables S1 and S2 in the Supplement; detailed information on the fire-scar records are in Holz and Veblen, 2011c). Sediment cores were collected using an $80 \mathrm{~mm}$ diameter by $1 \mathrm{~m}$ long piston corer at the Casanova (MCa) and Tortel (MTo) ombrotrophic peat bogs, dominated by Sphagnum spp. (hereafter mallines) in the Baker river watershed, and at the Leal mallín (MLe) in the Bravo river watershed. The sites are all located within small catchments $(<120 \mathrm{ha})$ and are open to the influence from fluvial inputs via streams or rivers in the catchment areas (see Fig. 1). At and nearby these three sediment sampling sites, a total of 13 bog forest or mallín sites were sampled for tree-ring fire scars; sample areas varied in size from ca. 10 to 120 ha (Fig. 1; Table S1 in the Supplement). All sediment and fire-scar sample sites are characterized by acidic and poorly drained soils as is common for Pilgerodendron forests (Pilgerodendron uviferum (D. Don) Florín (Guaitecas Cypress; Lara et al., 2006) the dominant tree species at all sites. P. uviferum inhabits ecotonal areas between well drained forested sites and valley bottom mallín sites characterized by pomponales (e.g. Sphagnum spp. and Carex spp.) and cushion (e.g. Astelia spp. and Donatia spp.) species. In well drained forests, $P$. uviferum mainly co-occurs with the broadleaved evergreen Nothofagus betuloides in our study area (Lara et al., 2006).

The study area is characterized by a west coast marine climate with relatively uniformly distributed precipitation and temperate conditions (Garreaud et al., 2009). Annual precipitation ranges from ca. 2000 to $4000 \mathrm{~mm}$ at sea level, increases with elevation (Garreaud et al., 2009). In the case that our sample areas had asynchronous fire peaks, the topographic and climatic characteristic of our study area were suitable for disentangling high versus low human impact on fire activity. The study area is characterized by rugged, glacial topography (Niemeyer et al., 1984) providing topographic barriers to charcoal dispersal. Pilgerodendron ecosystems are characterized by variable severity fire regimes (also known as mixed severity) in which both surface and crown fires occur (Holz and Veblen, 2009). Fire in the tall forests is dependent on more extreme drought than in the mallin vegetation where fine fuels are more easily desiccated.

\subsection{Sample processing and analyses}

\subsubsection{Sediment records}

Sediment cores where initially scanned through a Barrington Magnetic susceptibility loop at $1 \mathrm{~cm}$ intervals. This enabled us to identify mineral magnetic inputs associated with volcanic tephras or inwash events. The sediment cores were then sectioned in contiguous $1 \mathrm{~cm}$ samples for charcoal analysis and involved wet sieving $2 \mathrm{~cm}^{3}$ samples through 125 and 250 -micron sieves, lightly bleaching the coarse fraction in sodium hypochlorite $(6 \%)$ and counting black particles under a binocular dissecting microscope. Very low counts in the $>250$ micron category meant that the data were combined into one size class of $>125$ microns and expressed as a concentration of particles per $\mathrm{cm}^{3}$.

\subsubsection{Development of an age model}

Chronological control of the record was provided using ${ }^{14} \mathrm{C}$ dating of charcoal present in the cores. Charcoal was chemically cleaned by a series of $\mathrm{HCl}(1 \mathrm{~N})$ and $\mathrm{NaOH}(1 \mathrm{~N})$ baths at $80^{\circ} \mathrm{C}$ to remove secondary carbon deposits, exposing the original structural carbon lattice. The cleaned charcoal ( $\sim 2 \mathrm{mg}$ ) was then sealed into quartz reactors under 
vacuum and combusted at $900{ }^{\circ} \mathrm{C}$. The resulting $\mathrm{CO}_{2}$ gas was then cryogenically trapped and purified in a vacuum line and converted to graphite using $\mathrm{H}_{2}$ and iron oxide as a catalyst. The resulting graphite was then pressed into AMS target holders and analyzed at the KECK carbon cycle AMS facility of the University of California at Irvine. Radiocarbon ages are reported following the conventions of Stuiver and Polach (1977) and corrected for isotope fractionation using the AMS $\delta^{13} \mathrm{C}$ measurement. Calibrated radiocarbon dates from sixteen sediment samples ( 8 for mallín Casanova, 4 for mallín Tortel and 4 for mallín Leal; Table S2 in the Supplement) were used to develop a linear age-depth model (see below).

\subsubsection{Macroscopic charcoal analysis}

Macroscopic charcoal recovered from peat deposits is thought to consist of two components: a slowly changing "background", which represents the slow integration of charcoal from regional fire events through the filter of catchment transport processes (Whitlock and Millspaugh, 1996; Marlon et al., 2006); and short-lived charcoal "peaks", which are thought to represent charcoal produced by fire events occurring within a relatively local scale, plus charcoal contributed through sedimentary and analytical noise (Higuera et al., 2007). In order to reconstruct fire history close to the coring sites, the macroscopic charcoal time series was first plotted on the age model described above, interpolated into 25-yr bins (the median resolution of the records), and then converted into charcoal accumulation rates (particles $\mathrm{cm}^{-2} \mathrm{yr}^{-1}$ ). The charcoal accumulation series was then decomposed into background and peak components using CharAnalysis (Higuera et al., 2009; freely available at http://code.google.com/p/charanalysis/). Background charcoal was estimated by smoothing the charcoal time series to a 1000 yr window, using a locally weighted least squares regression robust to outliers. Residual charcoal values exceeding background levels were defined as the peak series. In order to distinguish "true" local fire events from noise-related variability in the peak series, we assumed that the peak series incorporates normally distributed variation around the background charcoal series (Gavin et al., 2006). In order to separate charcoal peaks from this noise, we used a Gaussian mixture model to estimate the mean and variance of the noise distribution. Fire events (identified by peaks in CHAR) were identified as peaks exceeding the 99th percentile of the noise distribution. Finally, peaks were subjected to a "minimum count test" which assesses whether a charcoal count identified as a peak has a $>5 \%$ chance being derived from the same population as counts for the previous five samples, assuming that charcoal counts are Poisson distributed around an unknown real value (Higuera et al., 2010b). In addition, Pearson correlation coefficients were computed between all charcoal accumulation rate (CHAR) records and background charcoals for the overall coinciding period to examine potential evidence of regional climatic controls on fire activity.

\subsubsection{Fire-scar based fire history records}

Fire-scar records were obtained exclusively from the species P. uviferum, mostly in bog-forests ecotonal conditions, but also in few adjacent well drained sites at $\sim 47-48^{\circ} \mathrm{S}$ in the rainforest district west of the Andes (see Holz, 2009). Five sample sites were located in the Baker and Quetru-Pascua watersheds, and three in the Bravo watersheds (Fig. 1). An average of 11 partial cross-sections (McBride and Laven, 1976) of fire scars were collected at each of the 13 Pilgerodendron sites, which yielded 4 to 8 cross-dated fire-scar samples per site (Holz and Veblen, 2011c). Cross-sections and cores were processed in the lab using standard dendrochronological techniques, including visual and statistical crossdating using COFECHA (Holmes, 1983). The crossdating process was conducted using existent (Roig and Boninsegna, 1990; Szeicz et al., 2000; Aravena, 2007) and newly developed P. uviferum tree-ring chronologies (Holz, 2009). According to convention for the Southern Hemisphere, years of annual rings and fire dates are assigned to the calendar year in which ring formation begins because the growing season extends across two calendar years (Schulman, 1956). The software program FHX2 (Grissino-Mayer, 1995) was used for graphing, filtering, and statistical analyses of the fire-scar data.

\subsection{Evaluating peat charcoal records and fire-scar records: detection and calibration}

To examine the correspondence between fire events derived from CHAR and from tree-ring fire scars, we created several versions of the fire-scar fire history record based on varying filters of the number and percent of minimum trees per site and minimum sites per watershed recording fire in a given year. To graphically compare the temporal correspondence between the CHAR record and the fire-scar record within each watershed, we aggregated the fire-scar data from all sites and created a record of all fire years (i.e. minimum of only one scarred tree in each site) and another of widespread fire years (i.e. minimum of two trees scarred per site and at least $20 \%$ of trees scarred in the study watershed). The $20 \%$ filter better reflects the influence of climatic conditions on fire probability and fire spread (as it is based on synchronous fire occurrence in several trees sampled in all sites within each watershed). The metric of all fire years (i.e. no filtering) is inherently more sensitive to variability in the frequency of small fires and therefore will better capture changes in local fire activity recorded at each cored mallín as macroscopic charcoal peaks.

To assess spatial correspondence between the charcoal and the fire scar records, we examine the variation of the paired and more distant fire-scar sites from the cored mallin in each 
watershed. For this, we smoothed the fire scar record (using a 25-yr locally weighted scatterplot smoothed means; Cleveland, 1979, since the CHAR records were interpolated to $25 \mathrm{yr}$ intervals; see above). At each site, the smoothing process used different time periods specific to both all fire years (no filter) and for widespread fire years (20\% filter; Table S1 in the Supplement). Potential correspondence between the fire scar and charcoal records was examined using Spearman's rank correlation coefficients as follows. First, correlations were computed between the CHAR record and the smoothed percent of trees burned in each of the fire scar sites within the same watershed during all fire years (i.e. minimum of only one scarred tree in each site). Both the CHAR and the all year fire-scar records reflect the "most local" fire events. Second, correlations were computed between the background charcoals and the smoothed percent of trees burned in each of the fire scar site within the same watershed during widespread fire years (i.e. minimum of two trees scarred per site and at least $20 \%$ of trees scarred in a site). Whereas the background charcoal could also reflect local fires that coincided with a year of extensive regional fires, background charcoal and the strongly filtered fire scar record reflect extra-local fire events over extensive areas. Background charcoal could also reflect ongoing movement of charcoal into the depositional space (i.e. the mallin), where charcoal can lie around in the catchment and be slowly eroded or washed into the bog and become background charcoal. Additional correlations were computed between the background charcoal and the smoothed percent of trees burned in each of the fire scar sites within the same watershed during all fire years. The purpose of this was to test the assumptions related to CHAR and background charcoal. As explained above, in our analysis, a "charcoal peak" had to exceed the 99th percentile of the noise distribution. However, we also identified CHAR values that were above background levels even if they did not meet the 99th percentile criterion. These correspondence analyses are interpreted taking into account the potential influence of the prevailing winds and the rugged topography.

\section{Results}

\subsection{Sediment stratigraphies and chronologies}

From mallín Casanova we obtained a $3.5 \mathrm{~m}$ sediment core (Fig. 2a). For the interval encompassing the last ca. $6370 \pm 20 \mathrm{yr}$ BP years the sediment core consists of brown fibrous peat, after which we found two layers of greybrown silty clay (before and after ca. $7165 \pm 25 \mathrm{yr} \mathrm{BP}$ ). The silty clays are likely to be derived from fluvial inputs related to stream inputs derived from the catchment. A shift to condition conducive to peat formation occur at $275 \mathrm{~cm}$ depth $(\sim 7500 \mathrm{cal} \mathrm{BP})$ and may relate to constrained drainage with as the catchment infilled with sediment or changes in precipitation. We found one tephra in the core (ca. 300$310 \mathrm{~cm}$ length) dated ca. $7165 \pm 25 \mathrm{yr}$ BP (Figs. 2a, 3), and it is believed to be derived from Volcán Hudson; correlating in time with $\mathrm{H} 1$ now dated at ca. $7500 \mathrm{yr}$ BP (C. R. Stern, personal communication, 2011) and with HW4 in the eastern Chonos Archipelago (Haberle and Lumley, 1998). Mineral magnetic inputs peak during the deposition of the tephra, despite being generally low in the peat and silty clay zones (Fig. 2a). There are a few minor inwash events of magnetic minerals from the present through to ca. $3400 \mathrm{yr}$ BP. We obtained a shorter core from the mallin Tortel $(1.75 \mathrm{~m}$ sediment core; Fig. 2b). At the mallín Tortel we obtained a sediment core that consists of brown fibrous Sphagnum peat encompassing the first $140 \mathrm{~cm}$, with a brown organic-rich clayey silt below it until the end of the core. No tephras were found in this core. Minor fluctuations in mineral magnetic inputs were also found in this core, with minor increases in the present, ca. $1000 \mathrm{BP}$, and right before $2855 \mathrm{BP}$ (Fig. 2b). From the mallín Leal, we obtained a $1.5 \mathrm{~m}$ sediment core that completely consists of brown fibrous Sphagnum peat (Fig. 2c). No tephras were found in this core. As in the previous cores, rather minor fluctuations in mineral magnetic inputs were found in this core, with minor increases in the present, ca. 155 BP, 285 BP, and right before 3190 BP (Fig. 2c).

\subsection{Charcoal analyses}

Charcoal accumulation rates (CHAR pieces $\mathrm{cm}^{-2} \mathrm{y}^{-1}$ ) at mallin Tortel show charcoal fluctuation over the last $3000 \mathrm{yr}$, with CHAR reaching prominent maxima in the 1970s AD and ca. 300 cal yr BP, 550 cal yr BP, $875-1375$ cal yr BP, $2100 \mathrm{cal} \mathrm{yr} \mathrm{BP,} 2375 \mathrm{cal} \mathrm{yr} \mathrm{BP}$, and $2975 \mathrm{cal}$ yr BP. A macroscopic charcoal peak is significant (from the background charcoal noise) only in the 1970s AD (Fig. 4a). From mallín Leal we obtained a charcoal record spanning the last four millennia with CHAR peaks in the $1950 \mathrm{~s} A D$, ca. 200 cal yr BP, 450 cal yr BP, 675 cal yr BP, 1150 cal yr BP, 1525 cal yr BP, 3375 cal yr BP, and 3750 cal yr BP (Fig. 4b). Most of these peaks were detected from the background noise, but did not reach significance $(P>0.05)$, except for the 1950s AD CHAR peak. In contrast to the previous two mallines, from the mallin Casanova we obtained a ca. 10 ka yr long charcoal record, with multiple detected (but not significant) CHAR peaks. Four significantly high CHAR peaks were found in $1920 \mathrm{~s} \mathrm{AD,} \mathrm{ca.} 700 \mathrm{cal} \mathrm{yr} \mathrm{BP}$, 8050 cal yr BP, 9850 cal yr BP, and 10200 cal yr BP (Fig. 4c). The CHAR records of the mallines located at the opposite ends of the Baker watershed (i.e. mallines Tortel and Casanova) show a strong temporal synchrony $\left(r_{P}=0.83\right.$, $P<0.05$ ), whereas mallin Leal was not strongly correlated with either of the CHAR records from the Baker watershed. The low variability in background charcoal amounts at mallines Leal and Tortel (Fig. 4) precluded the computation of correlations. 


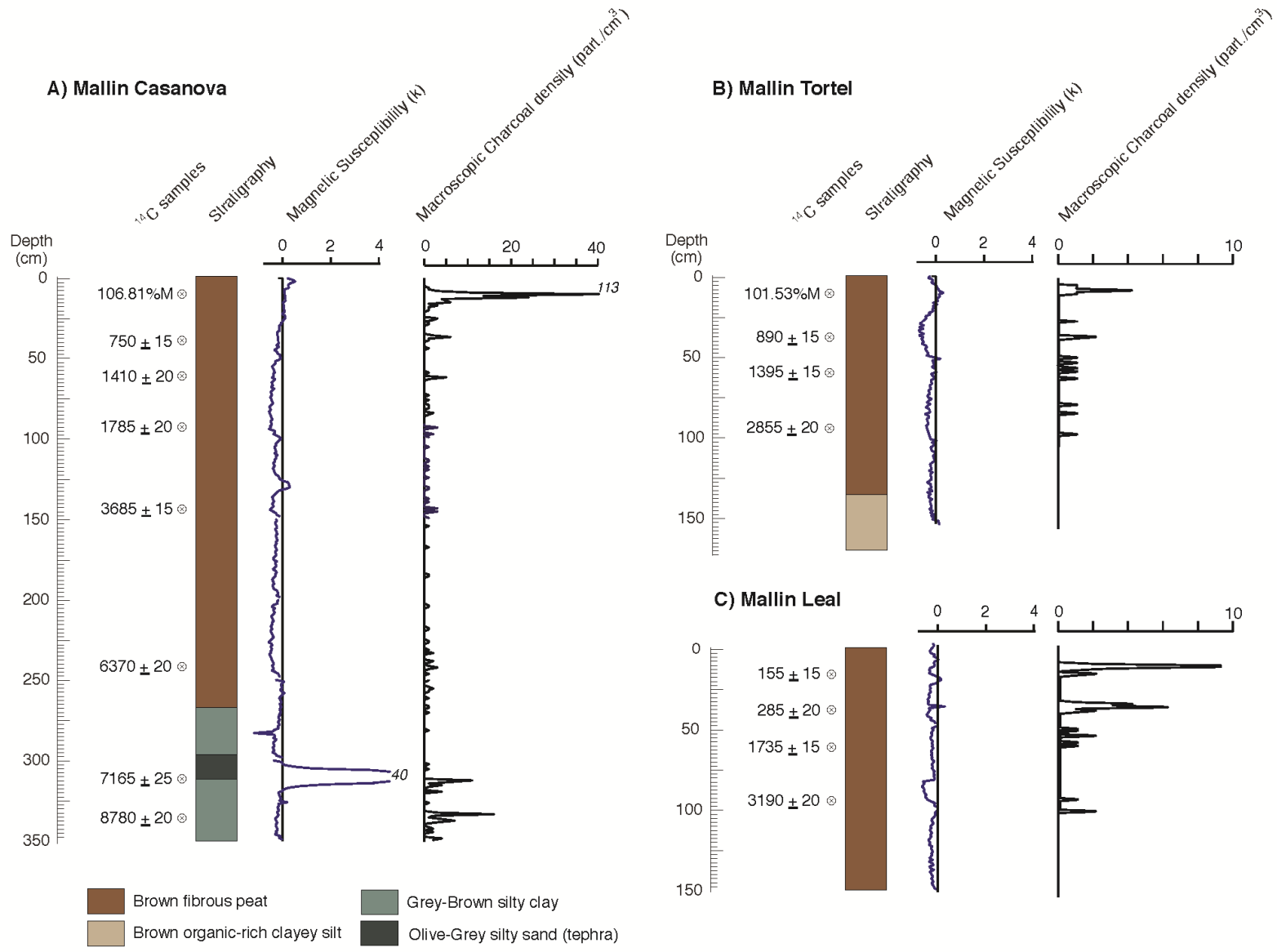

Fig. 2. Radiocarbon dates, stratigraphy, magnetic susceptibility, and macroscopic charcoal of each of the three sampled peats: (a) Casanova, (b) Tortel, and (c) Leal.

\subsection{Detection and calibration of the charcoal records using fire-scar records}

CHAR peaks tend to coincide with high fire activity recorded by tree-ring fire scars, but not all periods of frequent fire scars were recorded by the charcoal records (Fig. 5). There is a clear correspondence between both proxies in the 1950s1970s AD in all records (Fig. 5a, b); the high density of years with high percentages of sites recording fire scars corresponds with fire events in the 1950s-1970s AD. In the Baker watershed, there is overlap in the 1920s and the 1850 s between the mallín Casanova CHAR and the fire scar record (Fig. 5a). Despite the reduced sample depths in the aggregated fire scar record in the Baker watershed, there is some correspondence between the CHARs from both mallines and the fire scar records around the 1600s-1620s AD (Fig. 5a). At mallin Leal there is relatively strong correspondence of the CHAR record with the fire scar records in the 1920s and 1700s-1720s AD from both the Bravo and Quetru-Pascua watersheds (Fig. 5b). In both the CHAR and fire-scar records from all three watersheds, fire activity appears to decline in the 1920s and increase again in the 1940s (Fig. 5).
There is large variation in the correspondence between the CHARs and the fire scar records at each site as shown by the correlation coefficients. At the Baker watershed the samesite paired CHARs and fire scar records (during all fire years; circles) are highly correlated $(P<0.05)$, but the opposite is true at the mallín Leal (circles in Fig. 6a-c). As expected these correlations tended to decline over distance from the sedimentary sample site, yet at all three mallines the correlations were significant even for fire scar site most distant from the cored bog. At mallín Casanova, a high temporal correspondence $(P<0.05)$ was found between the background charcoal and all fire years record across the entire watershed (black squares in Fig. 6b). For mallin Casanova, high correlations also were found between the background charcoals and the record of widespread fire years within 10 kilometers from the coring site (inverted triangles in Fig. 5b). 


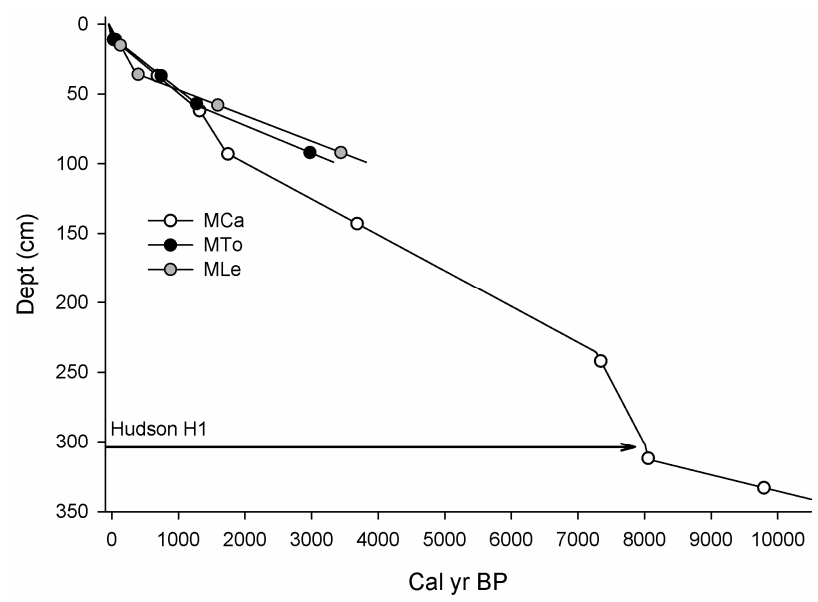

Fig. 3. Linear age-depth model for the composite charcoal records of the calibrated radiocarbon dates. ${ }^{14} \mathrm{C}$ dating errors range is $\pm 15-$ $25 \mathrm{yr}$ and is imperceptible at this age-scale resolution. The arrow indicates the position of the Hudson Vn. H1 tephra found in the mallín Casanova (MCa; see also Fig. 2a). MTo and MLe stand for mallines Tortel and Leal.

\section{Discussion}

\subsection{Fire history interpretations from sedimentary charcoal records}

\subsubsection{Transport and taphonomic processes uncertainties}

There is a high uncertainty regarding the production and deposition processes of sedimentary records from bogs and wetlands (Whitlock and Anderson, 2003). When sedimentary charcoal records are obtained from lakes, charcoal particles from terrestrial fires are generally assumed to have landed on lakes after being transported by wind or surface runoff. Topography influences post-fire runoff depending among other factors on slope angle of the burned hills and distance to the lake. In this study all sampled mallines are surrounded by rugged mountains with steep slopes that adjoin the sedimentary basin. However, the amount of charcoal that is produced in the catchment and then is subsequently deposited in the mallín sediments is unknown. In addition, an undefined percentage of the background charcoal might have been the result of in situ peat fires (Tolonen, 1983). Other studies of paired charcoal and fire-scar records in bog settings have suggested that a high percent of charcoal might not reach the deep sediments of bog interiors. This might be due to the fact that charcoal particles are filtered out by vegetation growing on the bogs and re-deposition is less common (Allen et al., 2008). In addition, changes in the sediment from silty clay to peat (e.g. Casanova mallín) would also have implications for the mode of input of charcoal into the sequence and requires further study to understand the drivers of this change. Despite these difficulties and uncertainties, high charcoal concentrations were found throughout the Holocene in the mallines sampled in the current study. Huber et al. (2004) and Markgraf et al. (2007) show that charcoal peaks in peat records are clearly defined without any "reworking" down core and can be found stratigraphically correlated across the bog. In the bogs studied here there could be instances when inorganic sediment influx (silty clay layers) may correlate with increased charcoal influx, though there is no evidence of this correlation occurring in the sediments stratigraphy. This is especially clear in all watersheds since the arrival and permanent establishment of Euro-Chilean settlers, where charcoal peaks and fire scar evidence closely cooccur. Other uncertainties related to bioturbation due to native or introduced mammals could be discarded in the study area. Native mammals are rare and generally prefer ridge habitats, and the introduction of cattle took place very recently (in the last ca. 30-70 yr; Holz and Veblen, 2011c) and should not have largely altered the stratigraphy of the sampled mallines.

\subsubsection{Detection and calibration of the charcoal records using fire-scar records}

Records of high fire activity derived from CHAR generally coincided with periods during which the fire-scar record also indicated at least some and usually abundant fire years. However, at annual and decadal time scales there were numerous instances in which the fire-scar record indicated moderate to high levels of fire activity that were not detected by the CHAR analyses. We speculate that some of the discrepancy between the two records may be a greater sensitivity of the fire-scar record to low-severity fire events that can be surveyed by fire-scar recording trees whereas low-severity fires may not be recorded in the sedimentary record. Highseverity (stand-replacing) fire events are more likely to be recorded in the CHAR record. Similar interpretations of the differential sensitivity of the two types of fire proxies to fires of different severities have been suggested for fire history records in the western US (Whitlock et al., 2004; Allen et al., 2008). In contrast, in a study conducted in boreal forests in Finland, fire activity recorded by both proxies corresponded well in a regime with low-severity and high fire frequency (Pitkänen et al., 1999). Another possibility is that since the early 1900s when vegetation conditions opened up (due to logging and increased fires by Euro-Chilean settlers), airborne charcoal particles were more widespread and more easily able to reach and deposit onto bogs. The shift from dense forest to more open woodlands may explain the improvement in the temporal match of the proxies after the early 1900s. This match however, should be taken with caution due to the absence of ${ }^{210} \mathrm{~Pb}$ dates in the development of our linear age-depth model based on radiocarbon dates only.

The spatial correspondence among the charcoal and fire scar records and their variations in the studied watersheds 


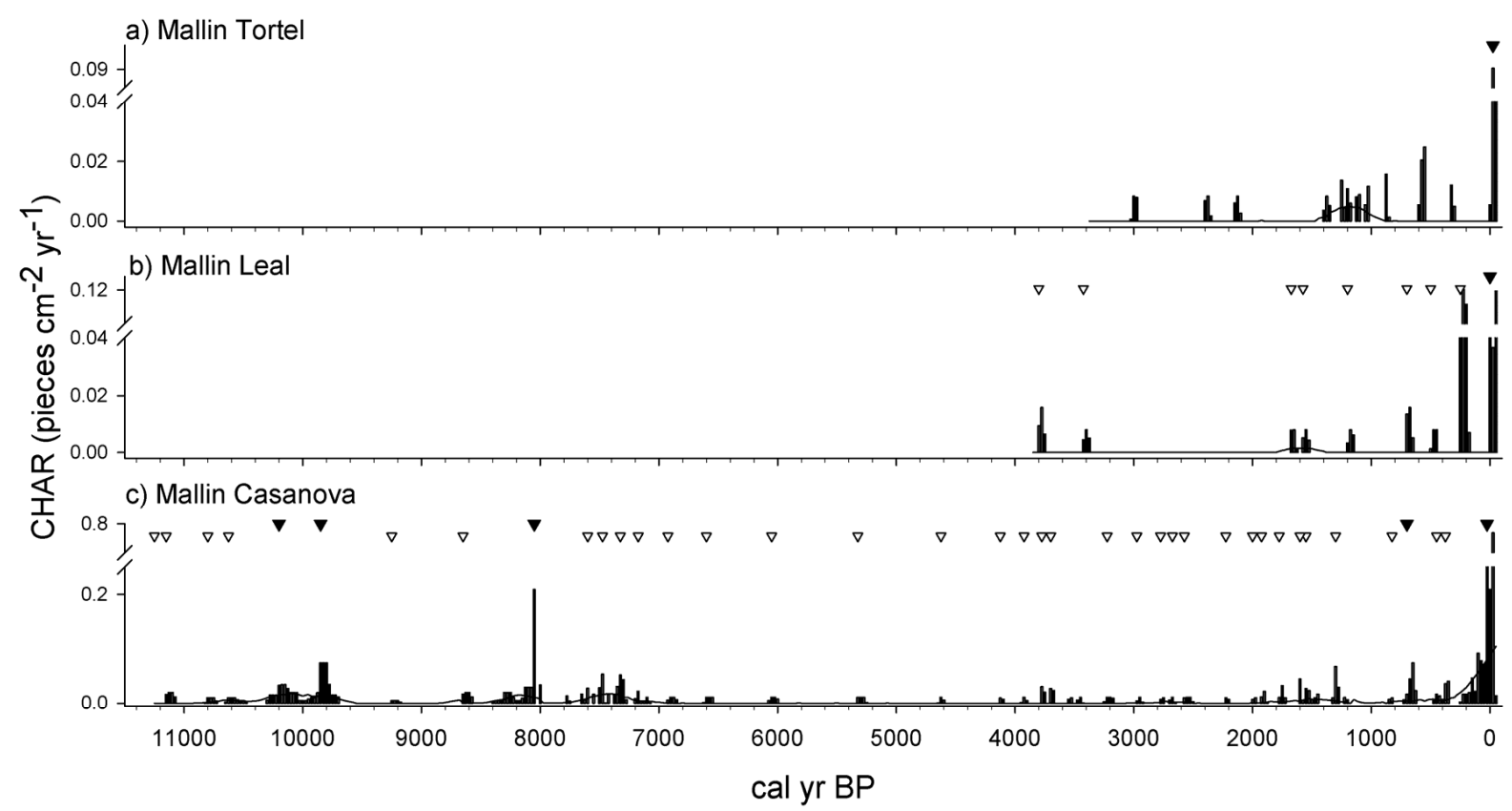

Fig. 4. Charcoal peak analysis using CharAnalysis (Higuera et al., 2009). Charcoal accumulation rates (CHAR pieces $\left.\mathrm{cm}^{-2} \mathrm{yr}^{-1}\right) \operatorname{are~}$ lotted on an age axis and interpolated to $25 \mathrm{yr}$ intervals. Background charcoal (black line) defined by 1000-yr trends. In order to separate charcoal peaks from the background noise, we used a Gaussian mixture model to estimate the mean and variance of the noise distribution. Fire events were identified as peaks exceeding the 99 th percentile of the noise distribution. $(P>0.05$, white inverted triangles; $P<0.001$, solid black inverted triangles).

indicate that these records might be affected by several factors. Among others, these include: the geographical alignment of the studied watershed in relation to the prevailing SWW, the rugged topography of the area, the strong precipitation gradient and the effect of moderate to severe drought on fire activity, human presence, the fuel type burned in previous fires and the criterion for selecting charcoal particle size. For instance, the predominant wind direction (westeast) could explain both the high correspondence between both CHAR records within the Baker watershed, and the low correspondence of these CHARs with the mallin Leal record. Similarly, in the Baker watershed both the CHARs from and fire-scar records at both mallines located at its opposite end are highly synchronous. Some variations however, could be explained by relative intensity of human activity as people may have preferred to occupy the more navigable Baker watershed, than the narrower canyons of the Bravo and QuetruPascua watersheds. In addition, since the Casanova mallin is located in slightly drier, eastward conditions than the other mallines (at least under current conditions), past fires could had been more severe and left a more readily identifiable charcoal record. Furthermore, at mallín Leal there was no correspondence between the local CHAR and its paired fire scar record. This could be explained by the abundant, insitu, fine fuels that characterized the study area and that could mostly create peaks of micro-particles $(<125 \mu \mathrm{m})$. Previous studies in similar ecosystems in the boreal forests in Finland found that micro-charcoal from both sediment cores and experimental burning were associated in some cases with local, rather than extra-local fire events (Pitkänen et al., 1999). Furthermore, in the Pacific Northwest in the US, ca. half of the low and moderate severity fires recorded by stand treeages and fire scars were detected in the sediment record, whereas all high severity were recorded synchronously by both proxies (Higuera et al., 2005). Therefore, the use of the 99th percentile for the peak detection might not be best suited for fine-fuel dominated mallines. In some areas, local events might be surface fire only, without the creation of large enough particles, and/or enough heat for currents of lifting air to travel extensively.

\subsection{Fire reconstruction and climate}

The charcoal records reported here extend by several thousand years back in time the existing fire history record for our study area in western Patagonia $\left(47-48^{\circ} \mathrm{S}\right)$, where previously only fire scar records existed for the ca. 1550-2005 period (Holz and Veblen, 2011c). Previous studies focused on fire activity both using fire-scar or charcoal emphasize the influence that climate and human activity have on fire regimes in the region (Veblen et al., 1999, 2011; Huber et al., 2004; Whitlock et al., 2007; Holz and Veblen, 2011c). 


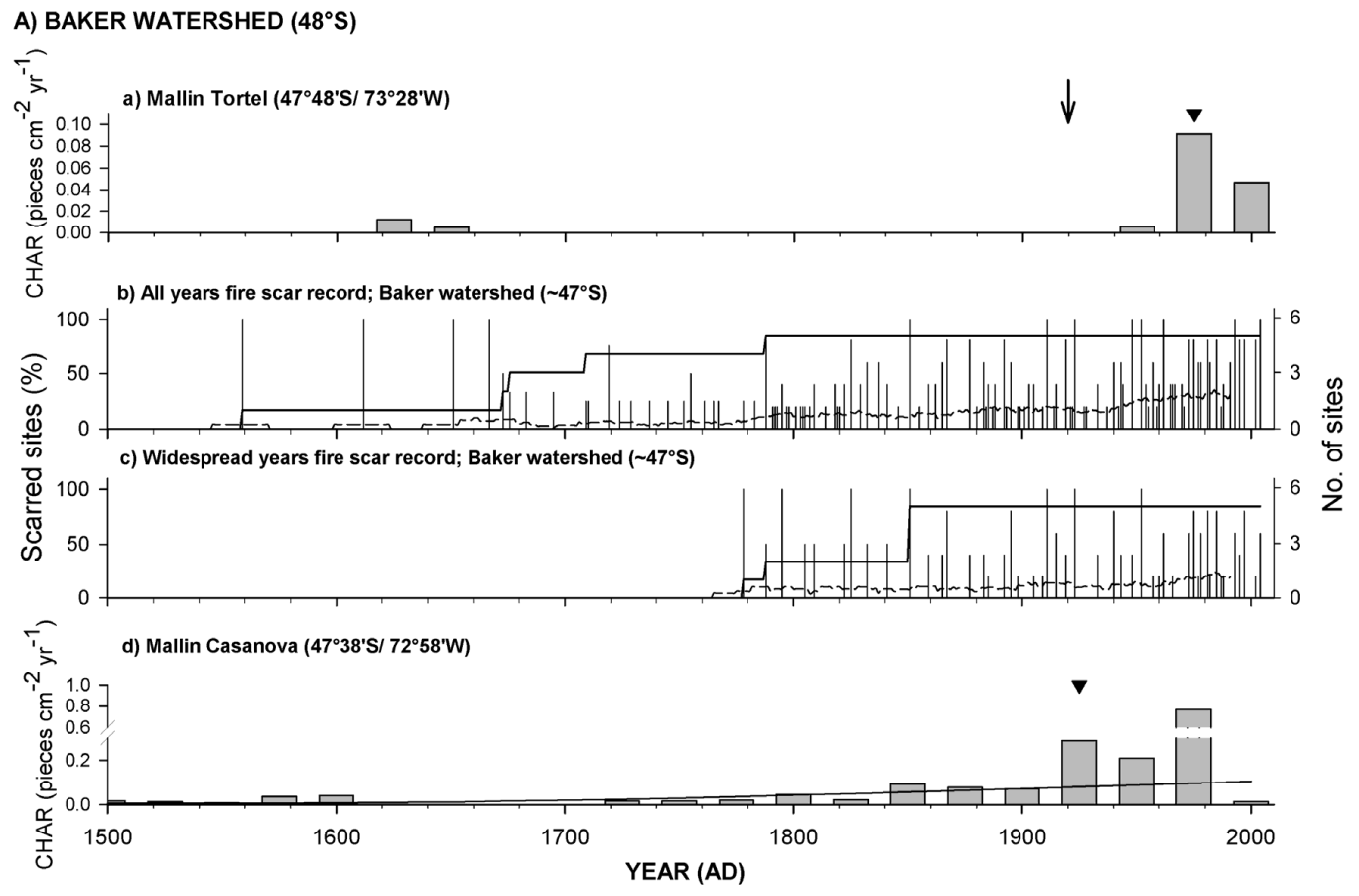

B) BRAVO AND QUETRU-PASCUA WATERSHEDS $\left(48^{\circ} \mathrm{S}\right)$
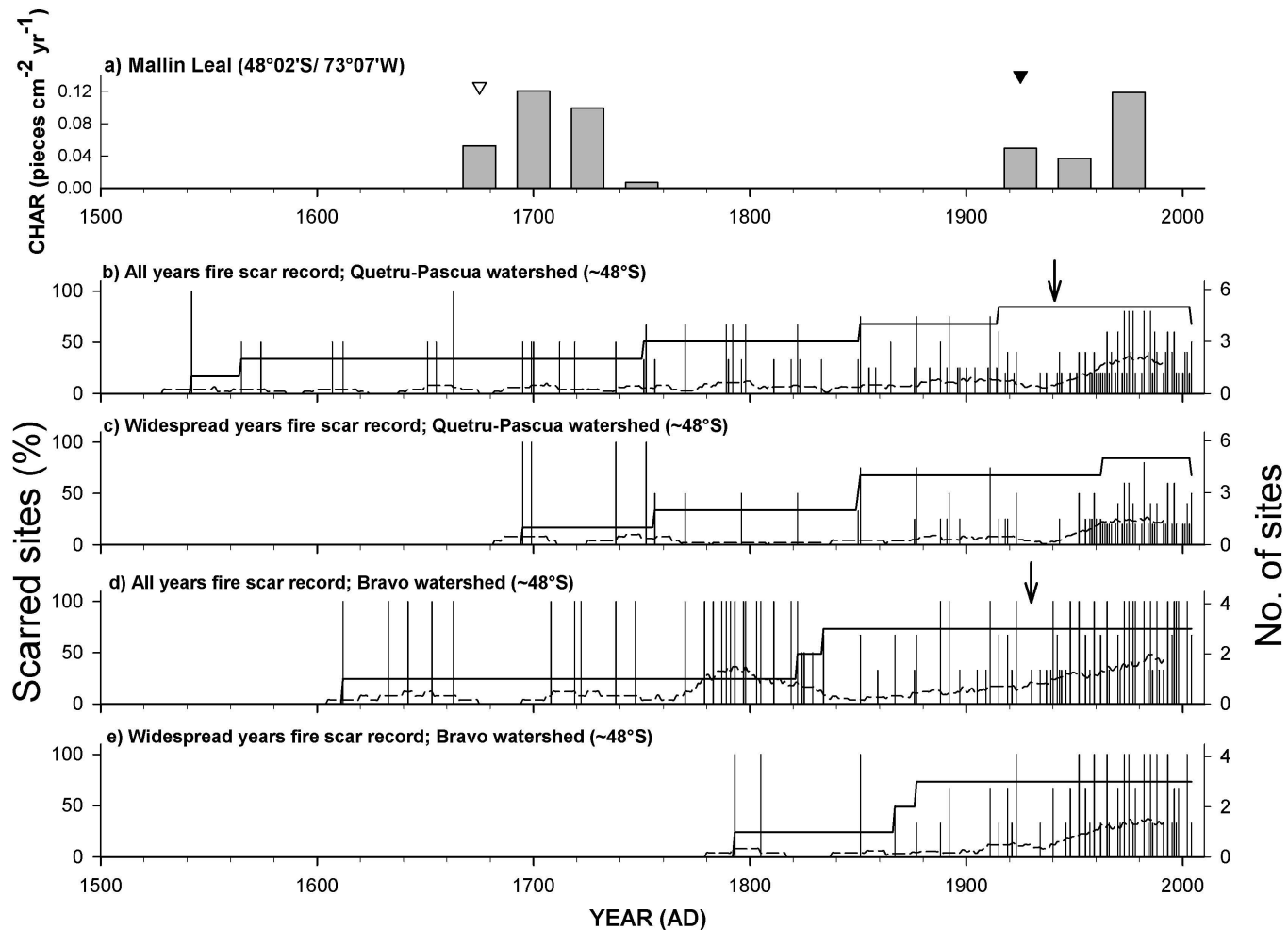

Fig. 5. Paired fire history based on fire scar and CHAR peaks in (a) the Baker watershed and (b) the Bravo and Quetru-Pascua watersheds. Fire scar indices for all fire and widespread fire years are presented by watershed. All fire years in the composite of each sample area are defined as (minimum $\geq 1$ scarred tree per site). Widespread fire years in the composite of each sample area are defined as (minimum of $\geq 20 \%$ of trees scarred in each watershed including individual sites that had a minimum of 2 scarred trees). The horizontal solid and dashed line in each fire scar composite represents the number of sites scarred in each watershed and a 25 -yr smoothed spline, respectively. The vertical arrow at each panel represents the Euro-Chilean period in each watershed as defined by Holz and Veblen (2011b). Note that the number of sites sampled varies among watersheds. CHAR values and symbols are defined in Fig. 4. 

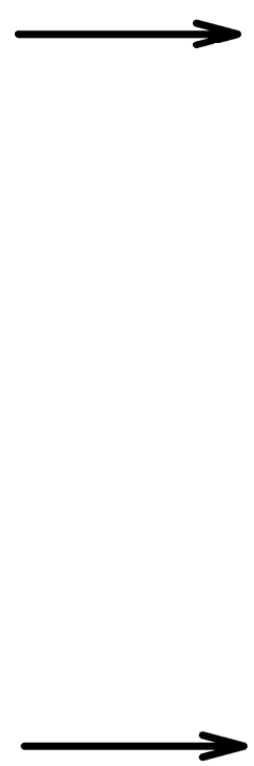
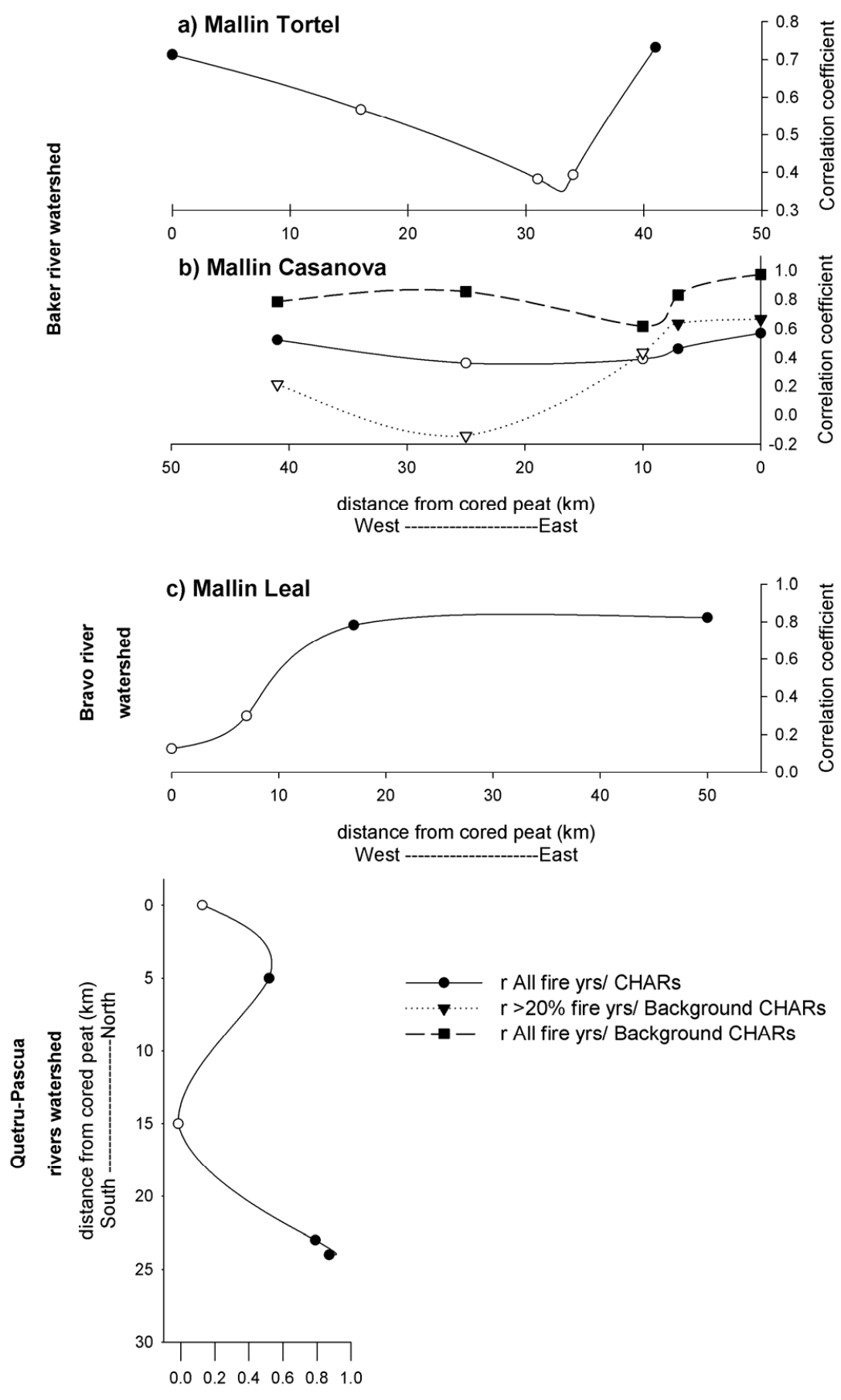

Correlation coefficient

Fig. 6. Spatial variation of correlation coefficients between individual fire scar records (smoothed) and the (a) mallín Tortel, (b) mallín Casanova, and (c) mallín Leal charcoal records. Circle, square and inversed triangle based scatterplots represent correlations between records of smoothed all fire years and CHARs, smoothed all fire years and Background CHARs, and smoothed widespread fire years and Background CHARs, respectively. Background CHAR records were found only in the mallin Casanova. Significant Spearman correlations $(P<0.05)$ between records are shown in solid symbols (i.e. black circles and inversed triangles), and all squares are significantly correlated. The horizontal and vertical displays of the panels represent the west-east and north-south gradients from each coring site, respectively. The black horizontal arrow represents the direction of the prevailing southern westerly winds (SWW) in relation to the sampled sites. The periods used for the smoothing of the fire scar records are in Table S1 in the Supplement. 
The relationship of fire activity to regional-scale climate variability is highlighted by the general correspondence between our fire records, previous charcoal records in the region, and reconstructed changes in precipitation in SSA. Changes in precipitation throughout the Holocene in SSA have been attributed to both ENSO events (Sepúlveda et al., 2009) and changes in the strength and/or latitude of the SWW (Varma et al., 2011). Overall (even under the unconstrained assumption of constant marine reservoir ages in the cited marine records), these relationships are currently valid as confirmed by studies using instrumental climate data (Montecinos and Aceituno, 2003; Garreaud, 2007; Garreaud et al., 2009). Under current climate conditions, the Southern Annular Mode (SAM), ENSO, and the decadal-scale ENSOlike Oscillation (i.e. expressed as PDO and IPO) are strongly teleconnected to precipitation patterns across SSA (Schneider and Gies, 2004; Garreaud et al., 2009; Fig. 7a).

Some of the synchronous charcoal peaks (e.g. 700, 1300 and $1600 \mathrm{BP}$ ) coincide with higher than average frequency of warm ENSO events (Moy et al., 2002; Koutavas and Sachs, 2008; Fig. 7b-e). Furthermore, and throughout the last ca. 11 thousand years, most of the identified charcoal peaks provide evidence that show temporally unstable support to both of the alternative hypotheses regarding the dynamics of the SWW and their influence on precipitation variability in SSA. One hypothesis supports the latitudinal shift of the SWW (Lamy et al., 2010; SWW-shift hypothesis hereafter), whereas the other hypothesis supports no shift, but instead zonally symmetric variation in the strength of the SWW (Moreno et al., 2010b; SWW-strength hypothesis hereafter). Consistent with the SWW-shift hypothesis, we identified fire events (e.g. ca. 700, 1300 and $1600 \mathrm{BP}$ ) that coincided with higher fire activity at $52^{\circ} \mathrm{S}$ (i.e. 1.2-1.8 ka yr; Moreno et al., 2009), and asymmetry among the precipitation records such as either high precipitation at $41-44^{\circ} \mathrm{S}$ (Fig. $7 \mathrm{~g}, \mathrm{~h}$ ) and low precipitation at $53^{\circ} \mathrm{S}$ (Fig. 7i), or low precipitation at $41^{\circ} \mathrm{S}$, high precipitation at $44^{\circ} \mathrm{S}$, and low at $53^{\circ} \mathrm{S}$ (Fig. $7 \mathrm{~g}-\mathrm{i}$ ). As recently proposed by Lamy et al. (2010), there is an analogy between the SSW dynamics throughout the Holocene and the modern SWW seasonal fluctuation. During the summer season the SWW's belt contracts and the intensity within its core $\left(\mathrm{ca} .53^{\circ} \mathrm{S}\right)$ strengthens, and during the winter the belt expands northward $\left(34^{\circ} \mathrm{S}\right)$ and wind intensity in the core $\left(53^{\circ} \mathrm{S}\right)$ decreases (Lamy et al., 2010). These seasonal patterns are primarily observed during the early and late Holocene, respectively (Lamy et al., 2010), and it is the winter pattern that fits with the precipitation patterns and charcoal peaks described above (i.e. late Holocene).

On the other hand, increased fire activity between 10.5 and $7.5 \mathrm{ka} \mathrm{yr}$ is evident in our stratigraphic record, as well as in others reported for northern Patagonia $\left(42^{\circ} \mathrm{S}\right.$, Moreno et al., 2001; $43^{\circ} \mathrm{S}$, Whitlock et al., 2006; Abarzúa and Moreno, 2008; $44^{\circ}$ S, Haberle and Bennett, 2004), southern Patagonia (ca. $52^{\circ} \mathrm{S}$, Huber and Markgraf, 2003; Huber et al., 2004), and Tierra del Fuego (ca. 55 ${ }^{\circ}$ S, Heusser, 1995; Markgraf and Huber, 2010). These records also coincide with regional decline in precipitation (Whitlock et al., 2007; Moreno et al., 2010a), thus supporting SWW-strength hypothesis (Moreno et al., 2010b; Fletcher and Moreno, 2011a). Overall, our record suggests that the two hypotheses are not mutually exclusive, and instead during different periods in the record one or the other hypothesis seems to be better supported. This interpretation is consistent with a recent synthesis (Fletcher and Moreno, 2011b) that suggests zonally symmetric changes in the SWW across the Southern Hemisphere during ca. 145 ka yr. Asymmetric patterns might have developed after ca. $5 \mathrm{ka}$ yr due to the onset of ENSO (Fletcher and Moreno, 2011b).

Overall, our results also highlight the millennial-scale influence of climate drivers other than ENSO on high fire activity (as shown by high charcoal concentrations in the late Holocene, prior to the onset of more frequent ENSO events; Fig. 7b-e). Previous climate-fire studies located at these same sites that were based on tree-ring fire records and used tree-ring based climate reconstructions showed that for the last ca. $250 \mathrm{yr}$, drought-events primarily resulted from the positive phase of SAM (Holz and Veblen, 2011a, b). The positive phase of SAM is associated with decreased surface pressure over Antarctica and a strengthening and poleward shift of the SWW (Garreaud et al., 2009), which results in lower precipitation in Patagonia (i.e. south of ca. $37^{\circ} \mathrm{S}$; Aravena and Luckman, 2009). A strengthening and/or poleward shift of the SWW could have resulted in the increased precipitation at $53^{\circ} \mathrm{S}$ in the early-to-mid Holocene (i.e. ca. 8 and $10 \mathrm{kyr} \mathrm{BP}$ ), which in turn fits with high charcoal peaks at our study area, and has been previously suggested by both SWW hypotheses (Lamy et al., 2010; Moreno et al., 2010b). Previous fire-climate studies have also indicated that when SAM was in its positive phase, fires were more frequent concomitantly with Pacific-wide warmer conditions at decadalscales (i.e. positive PDO; Holz and Veblen, 2011b). PDO is positively correlated with annual drought in southern Chile (Garreaud et al., 2009). Previous SST reconstructions also suggest that not all warming events of the coast of Chile at $41^{\circ} \mathrm{S}$ (Fig. 7f; Lamy et al., 2007) were directly caused by tropical Pacific ENSO (Fig. 7e; Moy et al., 2002) and/or the Cold Tongue Index (Fig. 7e; Koutavas and Sachs, 2008) records. Overall, this evidence suggests that large-scale climate modes with origins from both low- and high-latitudes (alone and in combination) have been teleconnected with drought events and fire activity in SSA.

\subsection{Fire reconstruction and people}

Interpretations of the relative roles played by humans versus lightning in accounting for long-term variations in wildfire activity have varied substantially. Whereas some authors have stressed the importance of prehistoric human activities (Heusser, 1987, 1994; Haberle and Bennett, 2004), others instead have highlighted the importance of climatic control and 
a)

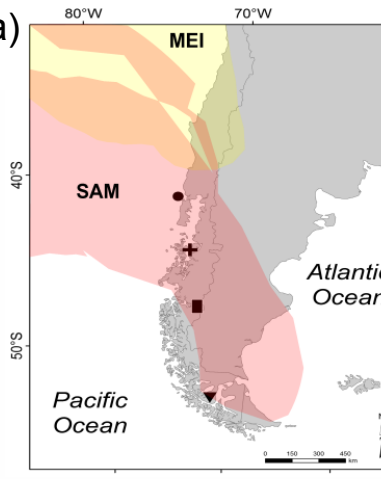

d) Mallin Casanova $\nabla \nabla \nabla \nabla \nabla$ b) Mallin Tortel

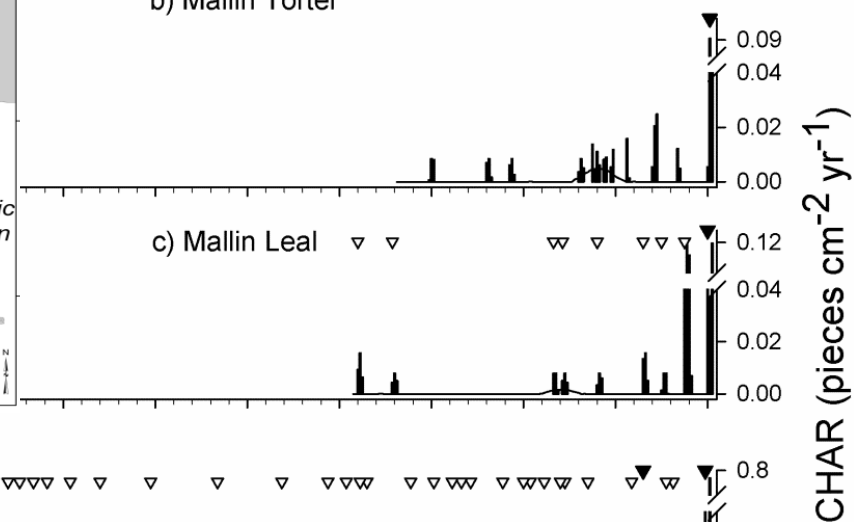

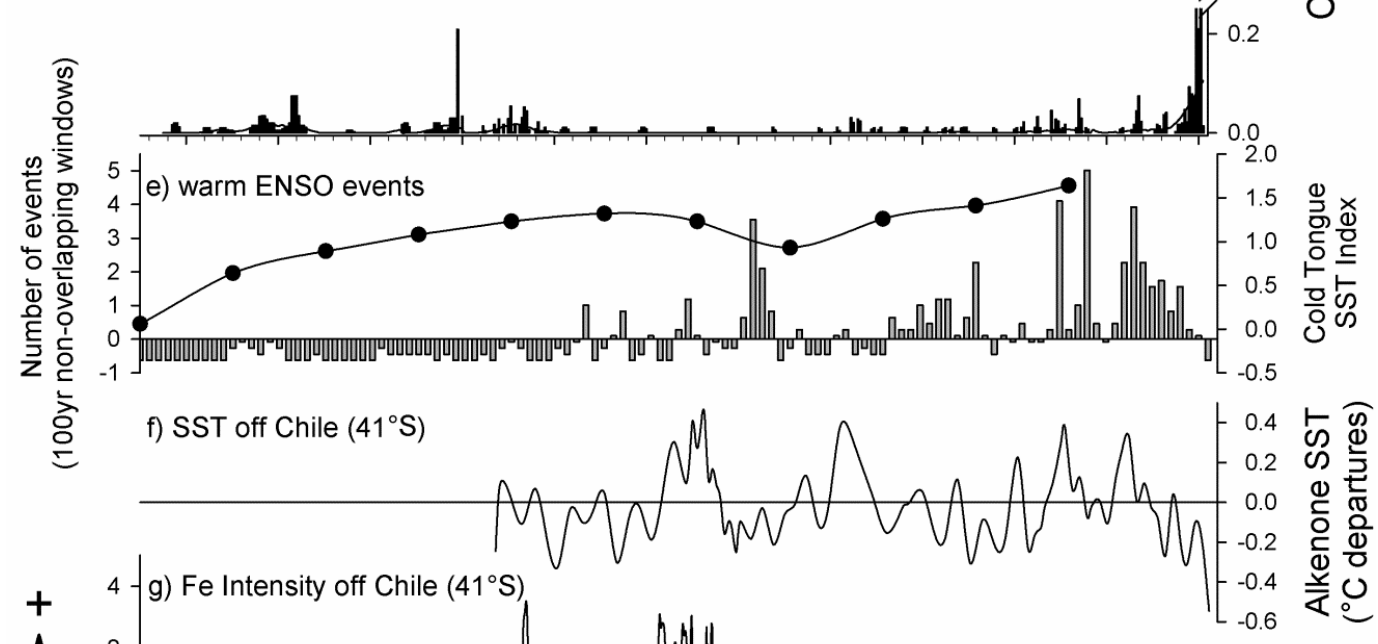

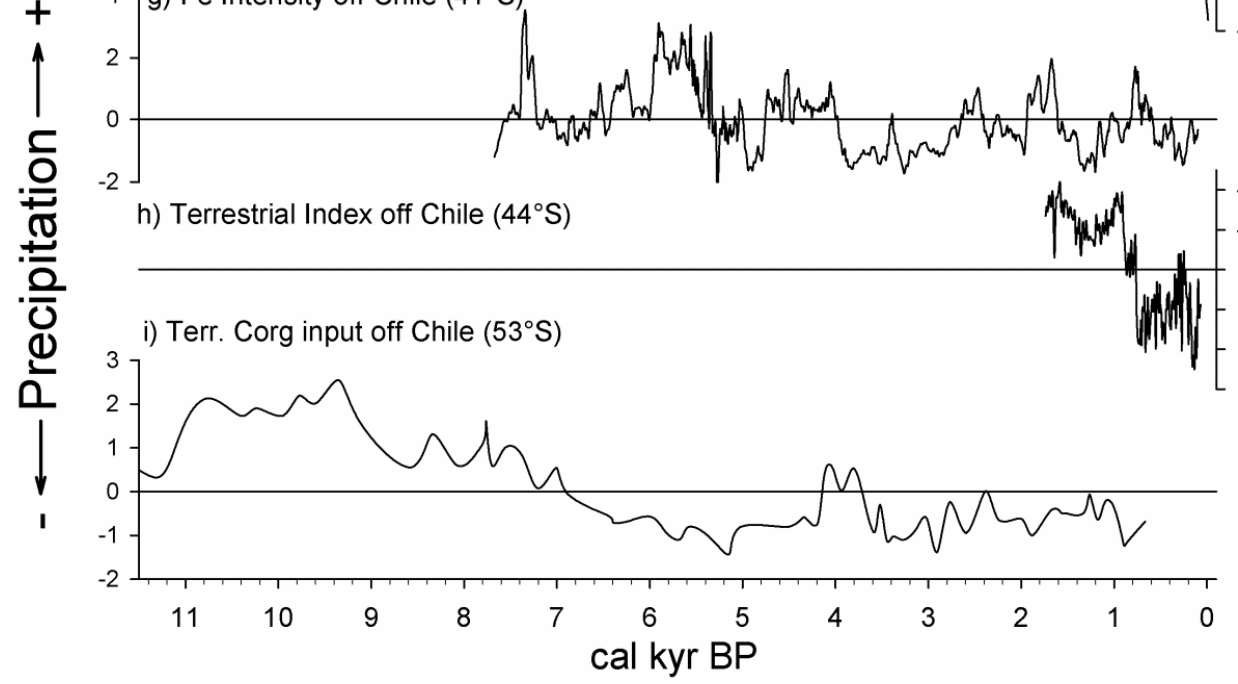

Fig. 7. (a) Regional-scale teleconnection between the Southern Annular Mode (SAM) and the Multiproxy ENSO Index (MEI) and precipitation in SSA for the 1957-2007 period (modified from the National Centers for Environmental Prediction-National Center for Atmospheric Research [NCEP-NCAR] Reanalysis; $2.5 \times 2.5^{\circ}$ grids; Kistler et al., 2001). CHAR peaks (b-d) and climate proxy. CHAR peaks as in Fig. 3, and climate reconstructions are for: (e) ENSO (bars; Moy et al., 2002) and Cold Tongue SST Index (Koutavas and Sachs, 2008), (f) Alkenone (SST at $41^{\circ} \mathrm{S}$; Lamy et al., 2007), (g) Fe intensity (precipitation and linked position of the southern westerly winds, SWW; based on the GeoB3313-1 iron record at $41^{\circ} \mathrm{S}$; Lamy et al., 2001), (h) Terrestrial Index (PC1 for the C/N ratio, $\delta^{13} \mathrm{C}$, and $\delta^{15} \mathrm{~N}$ at $44^{\circ} \mathrm{S}$; Sepúlveda et al., 2009), and (i) terrestrial organic carbon accumulation (precipitation and linked position of the southern westerly winds, SWW; based on core TML1 at $53^{\circ} \mathrm{S}$; Lamy et al., 2010). Antiphase trends between (g) the Cold Tongue SST Index and (i) the terrestrial organic carbon represents strength of SSW in SSA (Lamy et al., 2010). 
assumed that during the Holocene lightning ignitions were sufficiently frequent to not be a limiting factor (Markgraf and Anderson, 1994; Moreno et al., 2001).

Indigenous people are known to have inhabited the study area at the time of European arrival (Ivanoff, 2004). Archaeological (Goñi et al., 2004) and ethnohistorical (Martinic, 1977, 2005) evidence from southern Chile indicates that Indigenous people managed their landscape with fire. Furthermore, fire-scar based research in our study area indicates that prior to European arrival Indigenous people burnt more frequently than previously assumed (Holz and Veblen, 2011c). Our results provide new evidence of high correspondence between the CHAR records of the mallines located at the opposite ends of the Baker watershed (i.e. mallines Tortel and Casanova), but low correspondence with the mallin Leal record. Potentially, differences in local climatic conditions could account for the lack of correspondence but the two watersheds are at overlapping longitudes and separated by only ca. $28 \mathrm{~km}$. It is more likely, that under a common regional climate such disparity in fire activity suggests human presence in the Baker but not in the area of mallin Leal (at least for the last ca. 3-4 cal ka BP). Although published data are lacking, the consensus among archaeologist working in the region is that no prehistoric peoples inhabited our study areas before ca. $1000 \mathrm{BP}$ (F. Mena, personal communication, 2011).

There is no currently available archaeological evidence that support any human presence in our study area during the charcoal peaks of ca. 7-11 age cal ka BP (F. Mena, personal communication, 2011). Other than the influence of the Hudson eruption documented here (Fig. 2), these charcoal peaks suggest that climatic conditions were different than modern ones, and that lightning-set fires might have been more common than today. Although currently uncommon, lightninginduced fire scars were observed in our study area (Holz and Veblen, 2009), and lightning-set fires have more than tripled in northern Patagonia since the climate shift in the late 1970s (Veblen et al., 2008). This suggests that relative role of lightning as an ignition source probably also varied greatly over the Holocene, and that lightning observations during the 20th century may not provide completely suitable analogues for interpreting pre-historic records. Lack of lightning may account for the lack of charcoal peaks during the period from ca. 4700 to $5000 \mathrm{BP}$ when climate conditions were conducive to fire activity (i.e. dry periods at $41-44^{\circ} \mathrm{S}$ and at $53^{\circ} \mathrm{S}$ and warm ENSO peaks; Fig. 7e, g-i). In contrast, it appears that in the early Holocene climate conditions were conducive for convective storms and lightning was the source of ignition for the charcoal peaks recorded at mallin Casanova. In the mid-Holocene, climate conditions appear not to have been suitable for lightning set fires. With the arrival of Indigenous groups to the area in the late Holocene, fire activity was amplified by these groups during drought events. Since the arrival and permanent establishment of Euro-Chilean settlers, fire activity increased considerably and is clearly outside of the historical range of variability over most of the Holocene (Fig. 5; Holz and Veblen, 2011c).

\section{Conclusions}

Our study contributes relevant information to fire history in the western Patagonia rainforest region of SSA by examining temporal and spatial correspondence among charcoal and fire scars records in three watersheds. Our results show that CHAR records tend to coincide with the fire scar records during some periods, but in general they did not detect all periods of fire activity recorded by the tree-ring fire history record. Potentially, low severity fire events that burned mainly herbaceous and other fine fuels in mallines are not recorded in the sedimentary records of these bogs. This suggests that potentially, the procedure used for identifying fire events might not be best suited for fine-fuel dominated mallines. Despite these and other uncertainties about the production and deposition processes of sedimentary records from mallines, significant CHAR peaks were found throughout the Holocene.

Some of the fire events found in all three mallines are synchronous and tend to coincide with fire records from northern and southern SSA over a latitudinal span from ca. 42 to $55^{\circ} \mathrm{S}$, which indicates large-scale climate control on fire activity. Whereas the onset of more frequent ENSO events seems to be reflected by increased wildfire activity in the in the late Holocene, changes in the latitudinal position or intensity of the SWW appear to account for charcoal peaks in the early Holocene. Overall, it seems that fire activity throughout the Holocene in western Patagonia has responded to regional climate variation affecting a broad region of SSA that is teleconnected to both tropical- and high-latitude climate driversENSO and SAM. Although sources of ignition during the pre-historic period cannot be directly measured, the available archaeological knowledge of our study area strongly implies that the early Holocene peak in fire activity was not dependent on human presence. Finally, the increased fire activity during the 20th century that was concomitantly recorded by charcoal from all mallines and all fire scar sites is outside the range of variability characteristic of these ecosystems over many centuries and probably millennia.

\section{Supplementary material related to this article is available online at: http://www.clim-past.net/8/451/2012/ cp-8-451-2012-supplement.pdf.}

Acknowledgements. This research was supported by the National Geographic Society (grant 7988-06), the National Science Foundation (awards 0602166 and 0956552), the Beverly Sears Small Grants Program, and the Council on Research and Creative Research of the Graduate School at CU Boulder. For sharing with us his profound knowledge and observations on the archaeology of 
our study area, we thank Francisco Mena of the Centro de Investigación en Ecosistemas de la Patagonia (CIEP) in Coyhaique, Chile. We thank Frank Lamy and Julio Sepúlveda who kindly provided paleoclimate data. We also thank Vera Markgraf, Marcela Tonello, Patricio Moreno, Phil Higuera, and Ricardo Villalba for their insightful comments and suggestions which greatly improved our paper.

Edited by: R. Villalba

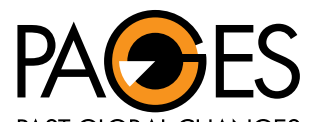

The publication of this article was sponsored by PAGES. (lago Salitroso-paso Roballos Arg/entrada Baker-río Chacabuco Chile), Chungará (Arica), 36, 1101-1107, doi:10.4067/S071773562004000400045, 2004 (in Spanish).

González, M. E. and Veblen, T. T.: Climatic influences on fire in Araucaria araucana-Nothofagus forests in the Andean cordillera of south-central Chile, Ecoscience, 13, 342-350, 2006.

Grissino-Mayer, H. D.: Tree-ring reconstructions of climate and fire history at El Malpaís National Monument, New Mexico, Ph.D. Dissertation, University of Arizona, 1995.

Haberle, S. G. and Bennett, K. D.: Postglacial formation and dynamics of North Patagonian Rainforest in the Chonos Archipelago, southern Chile, Quaternary Sci. Rev., 23, 24332452, 2004.

Haberle, S. G. and Lumley, S. H.: Age and origin of tephras recorded in postglacial lake sediments to the west of the southern Andes, $44^{\circ} \mathrm{S}$ to $47^{\circ} \mathrm{S}$, J. Volcanol. Geoth. Res., 84, 239-256, 1998.

Heusser, C. J.: Quaternary Pollen Record from Laguna-De-TaguaTagua, Chile, Science, 219, 1429-1432, 1983.

Heusser, C. J.: Fire history of Fuego-Patagonia, Quat. S. Am. A., 5, 93-109, 1987.

Heusser, C. J.: Paleoindians and Fire During the Late Quaternary in Southern South-America, Rev. Chil. Hist. Nat., 67, 435-443, 1994.

Heusser, C. J.: Paleoecology of a Donatia-Astelia Cushion Bog, Magellanic Moorland-Sub-Antarctic Evergreen Forest Transition, Southern Tierra-Del-Fuego, Argentina, Rev. Palaeobot. Palyno., 89, 429-440, 1995.

Higuera, P. E., Sprugel, D. G., and Brubaker, L. B.: Reconstructing fire regimes with charcoal from small-hollow sediments: a calibration with tree-ring records of fire, Holocene, 15, 238-251, doi:10.1191/0959683605hl789rp, 2005.

Higuera, P., Peters, M., Brubaker, L., and Gavin, D.: Understanding the origin and analysis of sediment-charcoal records with a simulation model, Quaternary Sci. Rev., 26, 1790-1809, doi:10.1016/j.quascirev.2007.03.010, 2007.

Higuera, P. E., Brubaker, L. B., Anderson, P. M., Hu, F. S., and Brown, T. A.: Vegetation mediated the impacts of postglacial climate change on fire regimes in the south-central Brooks Range, Alaska, Ecol. Monogr., 79, 201-219, doi:10.1890/07-2019.1, 2009.

Higuera, P. E., Whitlock, C., and Gage, J. A.: Linking tree-ring and sediment-charcoal records to reconstruct fire occurrence and area burned in subalpine forests of Yellowstone National Park, USA, Holocene, 21, 327-341, doi:10.1177/0959683610374882, 2010a.

Higuera, P. E., Gavin, D. G., Bartlein, P. J., and Hallett, D. J.: Peak detection in sediment-charcoal records: impacts of alternative data analysis methods on fire-history interpretations, Int. J. Wildland Fire, 19, 996-1014, doi:10.1071/WF09134, 2010b.

Holmes, R. L.: Computer-assisted quality control in tree-ring dating and measurement, Tree-Ring Bull., 43, 69-75, 1983.

Holz, A.: Climatic and Human Influences on Fire Regimes and Forest Dynamics in Temperate Rainforests in southern Chile, Ph.D., University of Colorado, 2009.

Holz, A. and Veblen, T. T.: Pilgerodendron uviferum: The southernmost tree-ring fire recorder species, Ecoscience, 16, 322-329, 2009.

Holz, A. and Veblen, T. T.: Wildfire activity in rainforests in western 
Patagonia linked to the Southern Annular Mode, Int. J. Wildland Fire, online first, doi:10.1071/WF10121, 2011a.

Holz, A. and Veblen, T. T.: The amplifying effects of humans on fire regimes in temperate rainforests in western Patagonia, Palaeogeogr. Palaeocl., 311, 82-92, doi:10.1016/j.palaeo.2011.08.008, $2011 b$.

Holz, A. and Veblen, T. T.: Variability in the Southern Annular Mode determines wildfire activity in Patagonia, Geophys. Res. Lett., 38, L14710, doi:10.1029/2011GL047674, 2011c.

Huber, U. M. and Markgraf, V.: European impact on fire regimes and vegetation dynamics at the steppe-forest ecotone of southern Patagonia, Holocene, 13, 567-579, 2003.

Huber, U. M., Markgraf, V., and Schabitz, F.: Geographical and temporal trends in Late Quaternary fire histories of FuegoPatagonia, South America, Quaternary Sci. Rev., 23, 1079-1097, 2004.

Ivanoff, D.: El Señor del Baker, Temuco, Chile, 224 pp. 2004.

Kistler, R., Collins, W., Saha, S., White, G., Woollen, J., Kalnay, E., Chelliah, M., Ebisuzaki, W., Kanamitsu, M., Kousky, V., van den Dool, H., Jenne, R., and Fiorino, M.: The NCEP-NCAR 50-Year Reanalysis: Monthly Means CD-ROM and Documentation, B. Am. Meteorol. Soc., 82, 247-267, doi:10.1175/15200477(2001)082<0247:TNNYRM>2.3.CO;2, 2001.

Kitzberger, T.: ENSO as a forewarning tool of regional fire occurrence in northern Patagonia, Argentina, Int. J. Wildland Fire, 11, 33-39, 2002.

Kitzberger, T. and Veblen, T. T.: Influences of humans and ENSO on fire history of Austrocedrus chilensis woodlands in northern Patagonia, Argentina, Ecoscience, 4, 508-520, 1997.

Kitzberger, T. and Veblen, T. T.: Influences of Climate on Fire in Northern Patagonia, Argentina, in: Fire Regimes and Climatic Change in Temperate Ecosystems of the Western Americas, edited by: Veblen, T. T., Baker, W. L., Montenegro, G., and Swetnam, T. W., 296-321, Springer-Verlag, New York, 2003.

Koutavas, A. and Sachs, J. P.: Northern timing of deglaciation in the eastern equatorial Pacific from alkenone paleothermometry, Paleoceanography, 23, PA4205, doi:10.1029/2008PA001593, 2008.

Lamy, F., Hebbeln, D., Röhl, U., and Wefer, G.: Holocene rainfall variability in southern Chile: a marine record of latitudinal shifts of the Southern Westerlies, Earth Planet. Sc. Lett., 185, 369-382, doi:16/S0012-821X(00)00381-2, 2001.

Lamy, F., Kaiser, J., Arz, H. W., Hebbeln, D., Ninnemann, U., Timm, O., Timmermann, A., and Toggweiler, J. R.: Modulation of the bipolar seesaw in the Southeast Pacific during Termination 1, Earth Planet. Sc. Lett., 259, 400-413, 2007.

Lamy, F., Kilian, R., Arz, H. W., Francois, J.-P., Kaiser, J., Prange, M. and Steinke, T.: Holocene changes in the position and intensity of the southern westerly wind belt, Nat. Geosci., 3, 695-699, doi:10.1038/ngeo959, 2010.

Lara, A., Donoso, C., Escobar, B., Rovere, A., Premoli, A. C., Soto, D., and Bannister, J.: Pilgerodendron uvifrerum (D. Don) Florin, in: Autoecología de las especies arbóreas de los bosques templados de Chile y Argentina, edited by: Donoso, C., Marisa Cúneo Ediciones, Valdivia, Chile, 2006.

Markgraf, V. and Anderson, L.: Fire history of Patagonia: Climate versus Human Cause, Revista do Instituto Geográfico do Sao Paulo, 15, 33-47, 1994.

Markgraf, V. and Huber, U. M.: Late and postglacial vegetation and fire history in Southern Patagonia and Tierra del Fuego, Palaeogeogr. Palaeocl., 297, 351-366, doi:10.1016/j.palaeo.2010.08.013, 2010.

Markgraf, V., Whitlock, C., and Haberle, S.: Vegetation and fire history during the last 18,000 cal yr BP in Southern Patagonia: Mallin Pollux, Coyhaique, Province Aisén $\left(45^{\circ} 41^{\prime} 30^{\prime \prime} \mathrm{S}\right.$, $71^{\circ} 50^{\prime} 30^{\prime} \mathrm{W}, 640 \mathrm{~m}$ elevation), Palaeogeogr. Palaeocl., 254, 492-507, doi:10.1016/j.palaeo.2007.07.008, 2007.

Markgraf, V., Whitlock, C., Anderson, R. S., and García, A.: Late Quaternary vegetation and fire history in the northernmost Nothofagus forest region: Mallín Vaca Lauquen, Neuquén Province, Argentina, J. Quaternary Sci., 24, 248-258, doi:10.1002/jqs.1233, 2009.

Marlon, J., Bartlein, P. J., and Whitlock, C.: Fire-fuel-climate linkages in the northwestern USA during the Holocene, Holocene, 16, 1059-1071, doi:10.1177/0959683606069396, 2006.

Martinic, M. B.: Ocupación y Colonización de la Región Septentrional del Antiguo Territorio de Magallanes, entre los paralelos $47^{\circ}$ y $49^{\circ}$ Sur, An. Inst. Patagon., 8, 5-57, 1977 (in Spanish).

Martinic, M. B.: De la Trapananda al Áysen, Pehuén Editores, Santiago, Chile, 2005.

McBride, J. R. and Laven, R. D.: Scars as an indicator of fire frequency in the San Bernardino Mountains, California, J. Forest., 74, 439-442, 1976.

Montecinos, A. and Aceituno, P.: Seasonality of the ENSO-Related Rainfall Variability in Central Chile and Associated Circulation Anomalies, J. Climate, 16, 281-296, 2003.

Moreno, P. I.: Climate, fire, and vegetation between about 13,000 and $9200 \mathrm{C}-14 \mathrm{yr} \mathrm{BP}$ in the Chilean lake district, Quaternary Res., 54, 81-89, 2000.

Moreno, P. I.: Millennial-scale climate variability in northwest Patagonia over the last $15000 \mathrm{yr}$, J. Quaternary Sci., 19, 35-47, doi:10.1002/jqs.813, 2004.

Moreno, P. I., Jacobson, G. L., Lowell, T. V., and Denton, G. H.: Interhemispheric climate links revealed by a late-glacial cooling episode in southern Chile, Nature, 409, 804-808, 2001.

Moreno, P. I., François, J. P., Villa-Martínez, R. P., and Moy, C. M.: Millennial-scale variability in Southern Hemisphere westerly wind activity over the last 5000 years in SW Patagonia, Quaternary Sci. Rev., 28, 25-38, doi:16/j.quascirev.2008.10.009, 2009.

Moreno, P. I., Kitzberger, T., Iglesias, V., and Holz, A.: Paleofires in southern South America since the Last Glacial Maximum, PAGES News, 2, 75-77, 2010a.

Moreno, P. I, Francois, J. P., Moy, C. M., and Villa-Martínez, R.: Covariability of the Southern Westerlies and atmospheric $\mathrm{CO}_{2}$ during the Holocene, Geology, 38, 727-730; doi:10.1130/G30962.1, 2010b

Moy, C. M., Seltzer, G. O., Rodbell, D. T., and Anderson, D. M.: Variability of El Niño/Southern Oscillation activity at millennial timescales during the Holocene epoch, Nature, 420, 162-165, doi:10.1038/nature01194, 2002.

Niemeyer, H. R., Skarmeta, J. M., Fuenzalida, R. P., and Espinosa, W. N.: Hojas Península de Taitao y Puerto Aisén, Región Aisén del General Carlos Ibañez del Campo, 1984 (in Spanish).

Pezza, A. B., Durrant, T., Simmonds, I., and Smith, I.: Southern Hemisphere Synoptic Behavior in Extreme Phases of SAM, ENSO, Sea Ice Extent, and Southern Australia Rainfall, J. Climate, 21, 5566-5584, 2008. 
Pitkänen, A., Lehtonen, H., and Huttunen, P.: Comparison of sedimentary microscopic charcoal particle records in a small lake with dendrochronological data: evidence for the local origin of microscopic charcoal produced by forest fires of low intensity in eastern Finland, Holocene, 9, 559-567, doi:10.1191/095968399670319510, 1999.

Roig, F. A. and Boninsegna, J. A.: Chiloé Island (Chile) summer precipitation reconstructed for 426 years from Pilgerodendron uviferum tree-ring chronologies, Lundqua Report, 32, 277-280, 1990.

Schneider, C. and Gies, D.: Effects of El Niño-Southern Oscillation on southernmost South America precipitation at $53^{\circ} \mathrm{S}$ revealed from NCEP-NCAR Reanalyses and weather station data, Int. J. Climatol., 24, 1057-1076, doi:10.1002/joc.1057, 2004.

Schulman, E.: Dendroclimatic Change in Semiarid America, University of Arizona Press, Tucson, Arizona, USA, 1956.

Sepúlveda, J., Pantoja, S., Hughen, K. A., Bertrand, S., Figueroa, D., León, T., Drenzek, N. J., and Lange, C.: Late Holocene sea-surface temperature and precipitation variability in northern Patagonia, Chile (Jacaf Fjord, $44^{\circ} \mathrm{S}$ ), Quaternary Res., 72, 400409, doi:16/j.yqres.2009.06.010, 2009.

Stuiver, M. and Polach, H. A.: Reporting of C-14 Data-Discussion, Radiocarbon, 19, 355-363, 1977.

Szeicz, J. M., Lara, A., Díaz, S., and Aravena, J. C.: Dendrochronological studies of Pilgerodendron uviferum in southwestern South America, in: Dendrocronología en América Latina, edited by: Roig, F. A., 245-270, EDIUNC, Mendoza, Argentina, 2000.

Tolonen, K.: The post-glacial fire record, in The role of fire in northern circumpolar ecosystems, edited by: Wein R. W. and MacLean, D. A., 21-44, Chichester, UK, 1983.

Varma, V., Prange, M., Lamy, F., Merkel, U., and Schulz, M.: Solarforced shifts of the Southern Hemisphere Westerlies during the Holocene, Clim. Past, 7, 339-347, doi:10.5194/cp-7-339-2011, 2011.

Veblen, T. T. and Lorenz, D. C.: Postfire Stand Development of Austrocedrus-Nothofagus Forests in Northern Patagonia, Vegetatio, 71, 113-126, 1987.
Veblen, T. T., Kitzberger, T., Villalba, R., and Donnegan, J.: Fire history in northern Patagonia: The roles of humans and climatic variation, Ecol. Monogr., 69, 47-67, 1999.

Veblen, T. T., Kitzberger, T., Raffaele, E., and Lorenz, D. C.: Fire History and Vegetation Changes in Northern Patagonia, in: Fire Regimes and Climatic Change in Temperate Ecosystems of the Western Americas, edited by: Veblen, T. T., Baker, W. L., Montenegro, G., and Swetnam, T. W., 265-295, Springer-Verlag, New York, 2003.

Veblen, T. T., Kitzberger, T., Raffaele, E., Mermoz, M., González, M. E., Sibold, J. S., and Holz, A.: The historical range of variability of fires in the Andean-Patagonian Nothofagus forest region, Int. J. Wildland Fire, 17, 724-741, 2008.

Veblen, T. T., Holz, A., Paritsis, J., Raffaele, E., Kitzberger, T., and Blackhall, M.: Adapting to global environmental change in Patagonia: What role for disturbance ecology?, Austral Ecol., 36, 891-903, doi:10.1111/j.1442-9993.2010.02236.x, 2011.

Whitlock, C. and Anderson, R. S.: Fire history reconstructions based on sediment records from lakes and wetlands, in: Fire and Climatic Change in the Americas, vol. 160, edited by: Veblen, T. T., Baker, W., Montenegro, G., and Swetnam, T. W., 3-31, Springer-Verlag, New York, 2003.

Whitlock, C. and Millspaugh, S. H.: Testing the assumptions of fire-history studies: an examination of modern charcoal accumulation in Yellowstone National Park, USA, Holocene, 6, 7-15, doi:10.1177/095968369600600102, 1996.

Whitlock, C., Skinner, C. N., Bartlein, P. J., Minckley, T., and Mohr, J. A.: Comparison of charcoal and tree-ring records of recent fires in the eastern Klamath Mountains, California, USA, Can. J. Forest Res., 34, 2110-2121, doi:10.1139/x04-084, 2004.

Whitlock, C., Bianchi, M. M., Bartlein, P. J., Markgraf, V., Marlon, J., Walsh, M., and McCoy, N.: Postglacial vegetation, climate, and fire history along the east side of the Andes (lat 4142.5 degrees S), Argentina, Quaternary Res., 66, 187-201, 2006.

Whitlock, C., Moreno, P. I., and Bartlein, P.: Climatic controls of Holocene fire patterns in southern South America, Quaternary Res., 68, 28-36, 2007. 